website: http://jsci.utq.edu.iq

Email: utjsci@utq.edu.iq

\title{
Evaluation of the Incidence and the State of Prophylaxis of Deep Vein Thrombosis and Pulmonary Embolism in Orthopaedic Patients in Al-Husain Teaching Hospital in Nasiriya
}

\author{
Wahby Ghalib Shaty \\ Department of Surgery - College of Medicine - Thiqar University
}

\section{$\underline{\text { Abstract }}$}

Thromboembolic disease affecting the venous circulation of the lower limbs and the pulmonary system is considered as a major source for morbidity and mortality in orthopaedic patients, both those who are trauma victims and those who underwent surgery. It includes two entities, deep venous thrombosis (DVT) and pulmonary embolism (PE). Clinical sequels of these include limb venous and arterial impairment as well as pulmonary vascular affection which can culminate in cardiogenic shock, which is a potentially lethal event. Over decades, there was intensive researching for the ideal methods for protection against these complications. The result was a lot of mechanical and pharmacological means which issued with both merits and demerits. In this study, we tried to evaluate several indices in regard to this topic in our locality. On the top of these is the state of awareness to the significance of these complications among those responsible for patient care provision. Also, to evaluate the various methods used regarding their frequency of usage and their effectiveness and the extent of employment of the low molecular weight heparins as considered now as the gold standard of prophylaxis. The final goal is to stress several recommendations that are aimed to raise the state of awareness to and handling of this medical problem.

تقييم معدل حصول الخثرة الوريدية العميقة والاتصمام الرئوي في مرضى جراحة العظام والمفاصل في مسنشفى الحسين(ع) التعليمي في الناصربة وتقييم الاجراءات الوقائية المتبعة

$$
\begin{aligned}
& \text { وهبي غالب شاتي } \\
& \text { قسم الجراحة - كلية الطب - جامعة ذي قار }
\end{aligned}
$$

\footnotetext{
الخلاصة

ان الخثرة الوريدية العميقة وما يتبعها من حصول الانصمام الرئوي والتي تؤثر في الاوعية الدموية للاطراف السفلى والجهاز الرئوي تعتبر من المضاعفات الطبية الكثيرة الحدوث في مرضى جراحة العظام والمفاصل سواء الذين يكونون منهم ضحايا للاصابات الهيكلية او الذين يخضعون لعمليات جراحية. وقد تؤدي الى حصول عواقب سيئة على صحة المريض او قد تؤدي احيانا الى الوفاة بسبب حصول الصدمة القلبية.وعبر عقود من البحث العلمي عن وسائل وقائية مناسبة لتجنب حصول هذه المضاعفات تم التوصل الى اجراءات ميكانيكية ودوائية عديدة علما ان كلا منها يحمل عددا من المزايا الجيدة والصفات الغير مرغوب بها. في هذه الدراسة توخينا تقييم العديد من العوامل السريرية ذات الصلة بهذا الموضوع وعلى رأسها حالة الوعي والاهنمام بهذا النوع من المضاعفات لدى القائمين على تقديم الرعاية الطبية للمريض.
} 
وكذلك معدل حصولها في مرضانا وماهو نوع الاجراءات الوقائية المتبعة ومدى فعاليتها ومدى استعمال دواء الهيبارين منخفض الوزن الجزيئي والذي يعتبر حاليا الوسيلة الوقائية الافضل. كل ذلك لكي نخرج بجملة من التوصيات لتحسين واقع التعامل مع هذه الحالة الطبية في محيطنا.

\section{Introduction}

Deep vein thrombosis (DVT) implies plateletbased occlusion of the venous flow. Its commonest site is the deep venous network of the lower $\operatorname{limb}(1)$. Its occurance is related to three main factors : venous endothelial damage, stagnation of the blood flow, and abnormal biochemical changes in favour of thrombus formation (Virtchow's triad)(2). Patients who sustained traumatic conditions and those undergoing surgical procedures have higher risk for developing deep venous thrombosis (1). Over decades there was perseverant pursuit for ideal pharmacologic prophylaxis for this condition.

The local manifestations for DVT include pain, swelling, tenderness and limitation of movement (3). Serious local complication, which usually associates big thromboses or thrombosis in an already- compromised vascular system, is the affection of the arterial blood flow of the limb (3). This occurs once there is considerable elevation of the venous blood pressure to interfere with the circulation (rubra and alba dolens conditions). However this serious condition is not common (3). The most serious complication of deep venous thrombosis, however, is embolization whereby a thrombus in the limb travels more proximally to entrap in and occlude a major venous system , usually the pulmonary arterial system (pulmonary embolism, PE)(3). The consequences of embolization may include cardiogenic shock if the embolus settles in the bifurcation of the pulmonary artery (4). This condition is potentially fatal. When embolization travels to a more distant site it may impose a range of consequences including hypotension, respiratory distress, and/or pulmonary infarction (4).

Statistically speaking deep venous thromboses that occur in the calf veins are about five times more common than those occuring in the more proximal veins (4). However the risk of pulmonary embolism is greater with the proximal thrombosis (5). Moreover it has been found that those thromboses that manifest themselves as local leg symptoms are less likely to cause embolization as they were found to be more adherent to the vascular endothelium(6).

The incidence rate of deep venous thrombosis in surgical patients depends on risk factors and ranges between $10-90 \%$ whereas risk of pulmonary embolism in these patients ranges between 0.5$12 \%(7)$. Pulmonary embolism is responsible for $6.5 \%$ of the annual deaths (6). $50 \%$ of the PEs are fatal $(7,9)$.

According to the American College of Chest Physicians (2004), the risk factors of deep vein thrombosis and pulmonary embnolism include the following :

1-age > 40 yrs. 2-immobilization. 3-obesity. 4stroke. 5-previous DVT.

6-congenital or acquired thrombophilia. 7-major surgery. 8-fractures of the pelvis or lower limb. 9varicose veins. 10-CVP line. 11-heart failure. 12Myocardial infarction. 13-pregnancy and puerperium. 14-high dose of oestrogen

15-inflammatory bowel disease. 16-nephrotic syndrome. 17-cancer(8).

Risk of thromboembolic disease in this study was graded into 3 groups.

Mild: when the patient has one risk factor, e.g. obesity or bed-riding for more than 48 hours.

Moderate: when the patient has two risk factors, e.g. pregnancy and lower limb surgery.

Severe: when the patient has three risk factors or more, e.g. diabetes, bed-riding and obesity.

We do believe that risk factors are not equal in magnitude and it is logic to give them individualized scores as well as to add scores to their different summation. However this necessitates thorough assessment of each risk factor. 
According to a research published in the American volume of the Journal of Bone and Joint Surgery in February-2004, the risk of deep venous thrombosis in orthopaedic patients provided no prophylaxis was 59\%, $47 \%$ and $41 \%$ for patients of total knee replacement, total hip replacement and fractured femur respectively(1).

Drugs which are used in DVT prophylaxis include the following :

\section{Antiplatelet drugs}

They include aspirin, dipyridamole, sulphinpyrazone and clopidogrel. They act by inhibiting cyclooxygenase -1 . They decrease the incidence of DVT by $30 \%$ and PE by $40 \%(10)$. Aspirin is active antiplatelet in low dose 50-150 $\operatorname{mg}(10)$.

\section{Warfarin}

It acts only in- vivo by inhibiting synthesis vitamin $-\mathrm{K}$ dependent clotting factors (factors $10,9,7,2)(10,11)$. It needs $36-72$ hrs to start action(11). It has rapid GI absorption (11) . It is bound to plasma proteins and has high bioavailability (11). The response to warfarin is variable and is affected by environmental, genetic and nutritional factors and intake of other drugs(11). The optimal prophylaxis is when INR between 2-3(11,17). It reduces DVT by 60$70 \%(11,17)$. Haemorrhagic complications occur in $3-5 \%(11,17)$. In case of warfarin toxicity: fresh frozen plasma and vitamin- $\mathrm{K}$ are needed (11).

\section{Heparin}

Unfractionated heparin acts both in -vivo and in-vitro by activation of antithrombin III which in turn acts by inhibition of factor $\mathrm{X}$ and thrombin. It has rapid onset and short half life( $1 \mathrm{hr})$. It is a mucopolysaccharide and represents a mixture of molecules with a molecular weight between 300030000 daltons. It is not given orally as is inactivated and its absorption is poor. It is given i.v. or s.c. but not i.m. as it causes haematoma. Prophylactic dose is low: $5000 \mathrm{U}$ Q8hrs. Haemorrhagic complications are $8-15 \%$. Treatment of heparin overdose: protamine sulphate is given in dose of $1 \mathrm{mg}$ for each $100 \mathrm{U}$ but not more than $50 \mathrm{mg}$ given i.v. slow over 10 minutes $(12,13,14)$.

\section{Low molecular weight heparins :}

Heparin is treated by enzymatic or chemical methods to separate the low molecular weight moieties. The average molecular weight is 15000 dalton. As the length of the molecular chain is decreased the ability to prolong PPT is lost so no need for monitoring. It has longer half life $(4 \mathrm{hr})$ so can be given once daily. There is no increment in haemorrhagic complications. Examples include: tinzaparin, dalteparin and enoxaparin. They can be administrated for prophylaxis $12 \mathrm{hrs}$ preop $(15,16)$.

\section{Aims of the study}

1-Evaluation of the extent of the problem of the thromboembolic disease (DVT and PE) in our locality.

2-Evaluation of the effectiveness of the various anticoagulant methods

3-Improving awareness of the physicians and surgeons to modern anticoagulant methods.

4-stressing the need for more accurate diagnostic methods for thromboembolic disease.

\section{Methodology}

This is an observational prospective study conducted in the department of orthopaedics in the Al-Husain teaching hospital in Nasiriya in the period between December 2011 and August 2012. 146 patients were followed up in the wards and the outpatient department in regard to the risk, prophylaxis and incidence of thromboembolic disaese. At the first time each patient was received a data form was filled including the general information, the reason for admission, past medical and surgical history and the procedure to be undertaken. Risk factors were determined. All patients were followed after undergoing the scheduled procedure and the method of anticoagulation (if any ) was recorded. Follow up was continued after discharge in the outpatient department and clinics. For patients who developed DVTs the condition was confirmed by Doppler 
ultrasound. The facility of venography is unfortunately lacking. Pulmonary embolism cases were confirmed using high resolution CT scan. The selection of patients was random. Both paediatric patients (less than 16 years ) and patients with upper limb conditions were excluded. Patients with unsatisfactory follow up were discarded from calculations.

The range of follow up checks was 3-6 times (mean 4). The duration of follow up was 30-56 days (mean 43 days). An important point which was affirmed is to exclude any thromboembolic case which occurred irregard to the original orthopaedic condition.

\section{$\underline{\text { Results }}$}

In this study, orthopaedic patients with lower limb and pelvic injuries and surgeries were followed. The various orthopaedic conditions found in the studied patients are clarified in figure -1 .

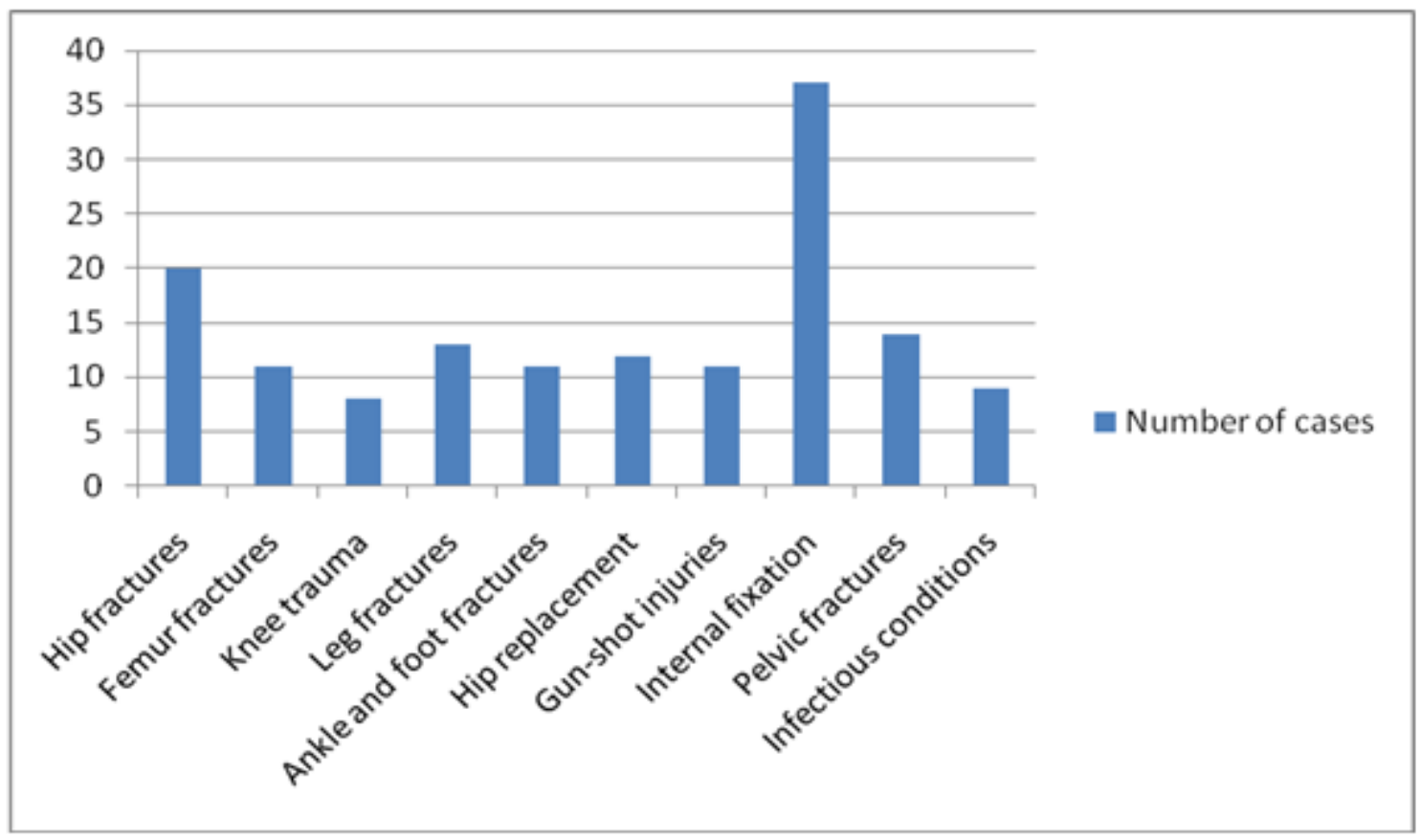

Figure -1 : Frequency distribution of orthopaedic cases in the study. 
Table -1 shows the age distribution of patients while figure -2 shows their sex distribution.

\begin{tabular}{|c|c|}
\hline Age category(years) & Number of patients \\
\hline $20-30$ & 34 \\
\hline $31-40$ & 36 \\
\hline $41-50$ & 28 \\
\hline $51-60$ & 24 \\
\hline$>60$ & 24 \\
\hline Total & 146 \\
\hline Mean & 43 years \\
\hline
\end{tabular}

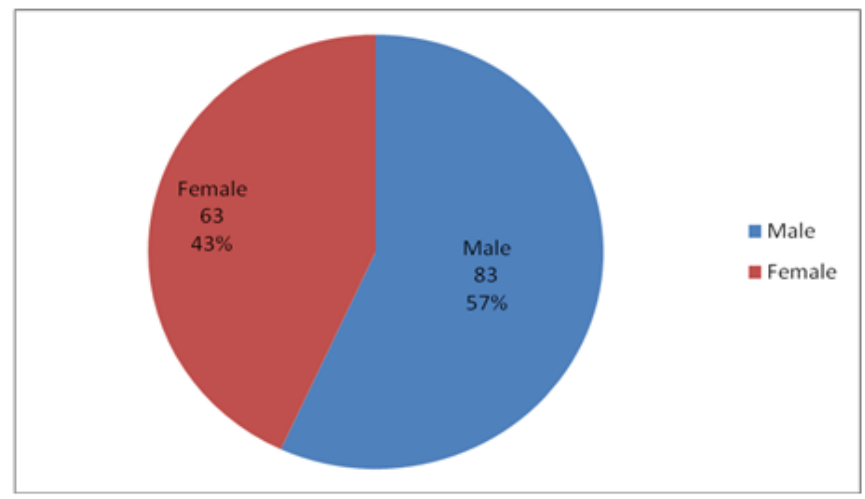

Figure -2 : sex distribution of patients.

According to the pre-mentioned categorization of the patients regarding the grade of risk, the distribution emphasized in table -2 is found.

Table -2 : Patients distribution according to the grade of risk.

\begin{tabular}{|c|c|c|}
\hline Risk category & number & Percentage \\
\hline Mild & 63 & $43.15 \%$ \\
\hline Moderate & 51 & $34.93 \%$ \\
\hline Severe & 32 & $21.91 \%$ \\
\hline Total & 146 & $100 \%$ \\
\hline
\end{tabular}

It is necessary to notice that in this study, no patient was risk - free as the study included patients with lower limb and pelvic injury or surgery only and this factor per se is considered as a risk factor for thromboembolic disease.

Regardless of the degree of the risk, not all patients were found to receive anti-thrombembolic prophylaxis and table -3 denotes the number and percentage of those who received prophylactic medication whatever the type of drug administered.

Table -3 : frequency distribution of patients according to provision of prophylaxis

\begin{tabular}{|c|c|c|}
\hline $\begin{array}{c}\text { Prophylaxis } \\
\text { provision }\end{array}$ & $\begin{array}{c}\text { Number of } \\
\text { patients }\end{array}$ & Percentage \\
\hline Yes & 79 & $54.1 \%$ \\
\hline No & 67 & $45.9 \%$ \\
\hline Total & 146 & $100 \%$ \\
\hline
\end{tabular}

The proportion of prophylaxis provision in each risk category are emphasized in table -4 . We can easily identify that there is no proportionate improvement in the rate of provision of prophylaxis with the increase in the risk.

Table -4 : proportion of prophylaxis provision in each risk category.

\begin{tabular}{|l|l|l|l|}
\hline Risk category & $\begin{array}{l}\text { Number and percentage } \\
\text { of patients who received } \\
\text { prophylaxis }\end{array}$ & $\begin{array}{l}\text { Number and percentage } \\
\text { of patients who did not } \\
\text { receive prophylaxis }\end{array}$ & Total \\
\hline Mild & $29(46.0 \%)$ & $34(54.0 \%)$ & 63 \\
\hline Moderate & $32(62.7 \%)$ & $19(37.3 \%)$ & 51 \\
\hline Severe & $18(56.2 \%)$ & $14(43.7 \%)$ & 32 \\
\hline Total & 79 & 67 & 146 \\
\hline
\end{tabular}

For the 79 patients where prophylaxis was provided different pharmacologic means were utilized as emphasized in figure -3 . 


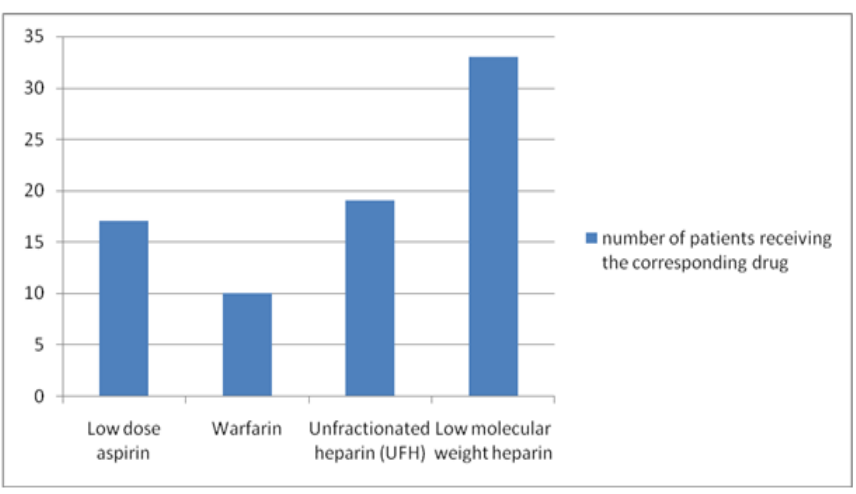

Figure -3: distribution of patients according to drug of prophylaxis.

During the period of the follow up the number of cases of deep venous thrombosis which were clinically evident and proved by investigations were 18 cases whereas the cases of pulmonary embolism were 5, two of them were fatal. None of these cases occurred in concomitance. During the period of follow up the number of patients died were 9,however only two of them were due to pulmonary embolism depending on clinical and autopsy basis. Both of the two fatalities occurred in unprotected patients. Table -5 clarifies the distribution of the cases of the both DVT and PE $(18+5)$ among the patients in the groups with and without prophylaxis.

Table -5: Distribution of DVT and PE cases in the groups with and without prophylaxis.

\begin{tabular}{|l|l|l|l|}
\hline Group & $\begin{array}{l}\text { Number of patients who } \\
\text { developed DVT or PE }\end{array}$ & $\begin{array}{l}\text { Number of patients who did } \\
\text { not develop DVT or PE }\end{array}$ & Total \\
\hline $\begin{array}{l}\text { Prophylaxis } \\
\text { provided }\end{array}$ & $5(6.3 \%)$ & $74(93.6 \%)$ & 79 \\
\hline $\begin{array}{l}\text { Prophylaxis not } \\
\text { provided }\end{array}$ & $18(26.8 \%)$ & $49(73.2 \%)$ & 67 \\
\hline
\end{tabular}

Regarding the 5 cases who developed thromboembolic complications in the protected group, 3of them were on low dose aspirin, 1 patient received warfarin and 1 patient received low molecular weight heparin.

\section{$\underline{\text { Discussion }}$}

Orthopaedic patients represent an inherently high risk group for the thromboembolic disease (17). This is due to prolonged periods of immobilization and because of the post-traumatic and post-opertaive chemical changes that favour thrombus formation $(18,19,20)$. This study found that more than $20 \%$ of orthopaedic patients with lower limb and pelvic conditions are at severe risk (table - 2). The incidence of thromboembolism in unprotected risky patients is about $27 \%$ (table -5 ), however the incidence is considered to be higher taking into account the subclinical cases and those cases in which the thrombus occurred in the proximal venous system for which the Doppler ultrasound is not sensitive enough to detect. As compared to the incidence of thromboembolism in the unprotected group and after implementation of the chi square test, the various anti-thrombotic drugs are found to be effective.

Table -3 clarifies that only $54 \%$ of those risky patients received prophylaxis. This points out to a considerable lack of awareness to the importance of this potentially lethal complication.

The information obtained from table -4 indicate that there may some lack of understanding of the concept of cumulative effect of risk factors (21). It is predicted that the increment in the number of risk factors is associated with proportionate increment in the use of antithrombotic prophylaxis. Actually, this was not the case. This may be explained in that there is individual variation among orthopaedic surgeons resulting in underestimation of the risk.

It is necessary to mention that not all risk factors are of the same magnitude. Despite this fact, any of the mentioned risk factors alone was assumed to put the patient in the mild risk category.

Regarding the cases where thromboembolism occurred despite prophylaxis, they mainly occurred in the group where Aspirin was administered. This agent is considered less effective than the anticoagulant drugs with DVT risk reduction of 
$33 \%$. It is better preserved for the time when the patient becomes fully ambulatory.

Both unfractionated heparin and warfarin are effective methods for prophylaxis (22). However, they are not preferred nowadays with the advent of low molecular weight heparins (22). They require close monitoring to achieve therapeutic level and to avoid hemorrhagic complications (22).

The mortality rate during the period considered clinically relevant to the orthopaedic condition was $6 \%$. However only 2 mortalities were proved to be due to thromboembolic disease. This makes the mortality rate $1.3 \%$. the two deaths occurred in the unprotected group; so if this is taken in consideration only, then it means that the mortality among risky patients not subjected to prophylaxis is about $3 \%$.

The type of low molecular weight heparin available in our hospital is enoxaparin (Clexane). For prophylactic purposes, it is administered in a dose of $4000 \mathrm{U} /$ day through deep subcutaneous rout with the first dose given 12 hours preop.

It is vital to stress that the extent of the problem of thromboembolic disease in surgical patients and especially in orthopaedics is not to be underestimated. It is a source of a significant morbidity and mortality. Also it is important to understand the concept of risk factors and to think of it in a cumulative way.

It is very cost-effective measure to cover the patient with antithrombotic medication. This will save time, money and hospital stay. However it is of great importance not to depend only on pharmacologic measures as even the best - proven antithrombotic medication has a failure rate. So, early mobilization and physiotherapy are important (23).

Various prophylactic drugs are available. However, the low molecular weight heparin nowadays is considered as the gold standard owing to the wide margins of both effectiveness and safety $(18,19)$. It is very important to improve the awareness of the surgeons to the usefulness and the right way of handling anti-thrombotic drugs. It is also important that these drugs under optimal conditions do not increase hemorrhagic complications. One last but important recommendation is that more clinically accurate diagnostic tools are needed to improve detection of thromboembolic disease. These include venography, fibrinogen scan and ventilation - perfusion scan (24).

\section{$\underline{\text { References }}$}

1-Archibald, DT . The Journal of Bone and Joint Surgery -American. Feb 2004.The risk of venous thrombosis in joint replacement surgery.

2-Dismuke, SE, Wagner, EH. Pulmonary embolism as a cause of death. The changing mortality in hospitalized patients. JAMA 1986.

3-Haeger K. Problems of acute deep venous thrombosis. I. The interpretation of signs and symptoms. Angiology. Apr 1969;20(4):21923.

4-Tapson VF. Acute pulmonary embolism. $N$ Engl J Med. Mar 6 2008;358(10):1037-52.

5- Meignan M, Rosso J, Gauthier H, Brunengo F, Claudel S, Sagnard L. Systematic lung scans reveal a high frequency of silent pulmonary embolism in patients with proximal deep venous thrombosis. Arch Intern Med. Jan 24 2000;160(2):159-64.

6- MCLACHLIN J, RICHARDS T, PATERSON JC. An evaluation of clinical signs in the diagnosis of venous thrombosis. Arch Surg. Nov 1962;85:738-44.

7-[Guideline] Snow V, Qaseem A, Barry P, Hornbake ER, Rodnick JE, Tobolic T. Management of venous thromboembolism: a clinical practice guideline from the American College of Physicians and the American Academy of Family Physicians. Ann Intern Med. Feb 6 2007; 146(3):204-10. 8-1- Hirsh, J, Raschke, R. Heparin and low-molecularweight heparin: the Seventh ACCP Conference on Antithrombotic and Thrombolytic Therapy. Chest 2004 
9-Horlander, KT, Mannino, DM, Leeper, KV. Pulmonary embolism mortality in the United States, 1979-1998: an analysis using multiple-cause mortality data. Arch Intern Med 2003.

10-Gerotziafas, GT, Samama, MM. Prophylaxis of venous thromboembolism in medical patients. Curr Opin Pulm Med 2004.

11-Kikura, M, Takada, T, Sato, S. Preexisting morbidity as an independent risk factor for perioperative acute thromboembolism syndrome. Arch Surg 2005.

12-Baglin, T, Barrowcliffe, TW, Cohen, A, Greaves, M. Guidelines on the use and monitoring of heparin. Br J Haematol 2006

.13-Hirsh, J, Anand, SS, Halperin, JL, Fuster, V. Guide to anticoagulant therapy: heparin: a statement for healthcare professionals from the American Heart Association. Circulation 2001.

14- Turpie, AG. Pharmacology of the lowmolecular-weight heparins. Am Heart J 1998.

15-Colvin, BT, Barrowcliffe, TW on behalf of BCSH Haemostasis and Thrombosis Task Force. The British Society for Haematology Guidelines on the use and monitoring of heparin 1992: Second revision. J Clin Pathol 1993.

16-Olson, JD, Arkin, CF, Brandt, JT. College of American Pathologists Conference XXXI on laboratory monitoring of anticoagulant therapy: laboratory monitoring of unfractionated heparin therapy. Arch Pathol Lab Med 1998.

17-Silverstein MD, Heit JA, Mohr DN, Petterson TM, O'Fallon WM, Melton LJ 3rd. Trends in the incidence of deep vein thrombosis and pulmonary embolism: a 25-year populationbased study. Arch Intern Med. Mar 23 1998;158(6):585-93.

18-Kakkar VV, Adams PC. Preventive and therapeutic approach to venous thromboembolic disease and pulmonary embolism--can death from pulmonary embolism be prevented?. J Am Coll Cardiol. Dec 1986;8(6 Suppl B):146B-158B.

19-Shepard RM Jr, White HA, Shirkey AL. Anticoagulant prophylaxis of thromboembolism in postsurgical patients. Am J Surg. Nov 1966;112(5):698-702.

20-Eskeland G, Solheim K, Skjörten F. Anticoagulant prophylaxis, thromboembolism and mortality in elderly patients with hip fractures. A controlled clinical trial. Acta Chir Scand. Jan-Feb 1966;131(1):16-29.

21- Hull RD, Pineo GF. Prophylaxis of deep venous thrombosis and pulmonary embolism. Current recommendations. Med Clin North Am. May 1998;82(3):477-93.

22-Ramzi DW, Leeper KV. DVT and pulmonary embolism: Part II. Treatment and prevention. Am Fam Physician. Jun 15 2004;69(12):2841-8.

23- Berend KR, Lombardi AV Jr. Multimodal venous thromboembolic disease prevention for patients undergoing primary or revision total joint arthroplasty: the role of aspirin. Am $J$ Orthop (Belle Mead NJ). Jan 2006;35(1):24-9.

24- Deitelzweig S, Jaff MR. Medical management of venous thromboembolic disease. Tech Vasc Interv Radiol. Jun 2004;7(2):63-7. 